\title{
ON ERADICATION OF WOODY PLANTS WITH HERBICIDES IN FIELDS AND PASTURES.
}

\author{
JaAkKo Mukula.
}

Agricultural Research Institute, Department of Plant Husbandry, Tikkurila.

Received 20.12. 49

\section{Introduction.}

Trees and shrubs which are capable of vegetative propagation may appear in fields and pastures as harmful "weeds". Vegetative propagation with these plants occurs from buds on the base of stems or on roots, and these buds develop shoots. Shoots developing from buds on the base of stem are called stem sprouts or stump sprouts, those developing from roots are called suckers. Sprouts and suckers often form thickets.

Many species of the woody plants growing in Finland form thickets of sprouts. The most important among these are grey alder, Almus incana (L.) WillD., and willows, Salix sp. Sometimes fields and pastures are so heavily infested with alder, that the growth of grass is totally inhibited. Alder thrives also in fields, on the banks of ditches, on the edges of fields, along roadsides, etc. Willows prefer moister lands, and are common on the banks of open ditches. The following species, among others, are commonly found in fields: Salix phylicifolia (L.p.p.) Sm, and S. caprea L. Willows are extremely common in Northern Finland. Thickets of sprouts are also formed by some other woody plants in our country, e.g. by aspen, Populus tremula L., and mountain ash, Sorbus aucuparia L., sometimes even by birch, Betula sp. (the commonest B. verrucosa (Ehrh.) Gunnarss., and B. pubescens (EHrh.) Gunnarss., and by birdcherry, Prumus padus L., and by buckthorn, Rhamnus frangula L., which thrive in the southern parts of the country. Of the abovementioned species, aspen and alder develop suckers, too. For alder they are of slight importance.

Up to the present date, attempts to eradicate thickets of sprouts in our country have been carried out by means of sprout scythes or billhooks, and the plants are usually cut down towards Midsummer. By this time most of the food in the roots of the plants has been used up for forming leaves. If slanting and high stumps are left when cutting the sprouts, their regeneration is slighter than if level and low 
stumps are left. On the whole, eradication of thickets of sprouts by this method has not been successful, and in a short time new thickets, denser than before, have developed from stumps. Thus it has been necessary to repeat the treatment, which requires both time and labour, in many successive years, sometimes even twice a year, before thickets have been eradicated. It is very difficult to destroy thickets by means of ordinary methods of cultivation, if sprouts, their roots included, are not hoed up, or pulled up by machines. Hoeing requires much time and labour, and it is not possible to get mechanical clearing machines for small areas. Besides, it is not possible to prepare stony soils effectively enough to destroy thickets, and most pastures in Central and Eastern Finland are on stony soils. Insufficient ground preparation is the commonest reason for formation of thickets on cultivated fields. Other methods formerly used for destroying sprouts are e.g. covering of stumps with earth, and drying of standing trees by barking their trunks.

During the last decades, attempts have been made to use chemicals for eradication of woody plants. Treatment may then be applied to leaves, stems, stumps, or soil. L e a v e s have been mostly treated with artificial hormones, 2,4-dichlorophenoxyacetic acid or chloroxone (2,4-D), and 2-methyl-4-chlorophenoxyacetic acid or methoxone (2M-4K), usually applied as sprays. In U.S.A., Hamner and TUkeY (4), LEONARD and HERZEL (12), and some other investigators (1) have experimented with $0.2-0.3 \%$ concentrations of $2,4-\mathrm{D}$ in solutions. Compounds in ester form proved the most effective. In Sweden, RenNERFELT $(23,24)$ used $0.1-0.4 \%$ 2M-4K for spraying sprouts of birch. Also Osvald and ÅBERG (21) have observed that most species of broadleaf woody plants were susceptible to sprayings with artificial hormones. In Finland, Hilli (5) used 2,4-D and $2 \mathrm{M}-4 \mathrm{~K}$ sprays at $0.1 \%$ concentrations at the rate of 1000 1. per ha. He mentions that alder is very susceptible, birch, mountain ash, bird-cherry, and willow fairly susceptible, and aspen as well as buckthorn slightly more resistant than the others. Later (6) he reports that the required concentrations of the ester of 2,4-D are $0.1-$ $0.3 \%$, and those of the sodium salt of $2 \mathrm{M}-4 \mathrm{~K}$ three times higher. Application of artificial hormones to leaves is most effective in the early summer, and it should be carried out in warm weather. Plants must be sprayed so carefully that all branches come into contact with the solution. In Sweden, LindFors (11) experimented spraying with sodium chlorate, and reports that concentrations of $7-8 \%$ proved effective. CopE and SpaEth (2) applied sodium arsenite to the $\mathrm{s} t \mathrm{e} \mathrm{m}$ of a standing tree, in a solution containing $2 \mathrm{lb}$. of $\mathrm{As}_{2} \mathrm{O}_{3}$ per gal. $(=239 \mathrm{~g}$. per 1.) Rennerfelt (23), in a similar manner, applied 5.30 g. of sodium arsenite, and $3 \mathrm{~g}$. of $2 \mathrm{M}-4 \mathrm{~K}$ per tree. Hamner and Tukey (4) applied 2,4-D to the stem of a standing tree. Application to stems is reported to be most effective, if the chemical is applied to a cut made in the sapwood. Cope and SPAETH obtained the best results by applications in autumn or in winter, RENNERFELT by applications in June or July. In this connection it may be mentioned that experiments are made to apply chemicals to stems in order to dry trees for industries out on the stumps, when their bark may be easily removed for a considerable period of time $(3,16,17,18)$. Arsenic has proved the most effective for this purpose, but also 
ammonium sulphamate, sodium chlorate, and 2,4-D have given promising results. Several chemicals have been applied to st u m p s by Imenberry, Bruce, and CURRY (7). They report that sodium arsenite (at a concentration of $25 \%$ ), sodium chlorate (at a concentration of $12 \%$ ), and $27^{\circ}$ API Diesel oil kill $85 \%$ of the stumps. Application is made to cuts girdling the stump at the ground level. After application the cut is covered with earth, if the applied chemical is poisonous. Cope and SpaEth, and Rennerfelt report that sodium arsenite is much less effective if applied to a stump than if applied to the stem of a standing tree. In U.S.A., during the last few years esters of 2,4-D have been applied to stumps in solutions of high concentrations. The substance is applied to the cut surface of the stump (1). If applied to s o i l, the effect of chemicals on woody plants is slight, according to IKEnBERry, Bruce, and Curry (7). Also Hilli (5) obtained a similar result in his experiments with potassium chlorate. It is usual to apply sodium chloride to the soil to destroy Berberis vulgaris L.

According to many investigators, of the above-mentioned chemicals those containing arsenic are the most effective, and also the cheapest $(2,3,7,16,17,18)$. The poisonous qualities of arsenic, however, limit their use, whereas the general use of many other effective chemicals is restricted by their high costs. During the last years great expectations have been directed to artificial hormones $(1,3,4$, $5,6,12,23,24)$.

At the Department of Plant Husbandry of the Agricultural Research Institute, experiments were begun in 1948 to eradicate woody plants, chiefly on fields and pastures, with chemicals, in connection with investigations on weed control. In the present study these experiments, in which a r t ificial hormones, potassium chlorate, and chresol ${ }^{1}$ were used as herbicides, are reported. At the same time, attentio is paid to the translocation of chemicals in different parts of woody plants.

\section{Spraying experiments.}

Sprayings at Agricultural Research Institute were chiefly given to thickets on dry clay and sandy soils. The number of treated plots, as well as plants, and their heights are given in the following tabulation (the area of plots $10-50 \mathrm{~m}^{2}$ ):

$\begin{array}{rccl}\text { Number of plots } & \begin{array}{c}\text { Height of thicket } \\ \mathrm{m} .\end{array} & \begin{array}{c}\text { Age of thicket } \\ \text { years }\end{array} & \text { Species of plant } \\ 25 & 1-2 & 2-4 & \text { Alnus incana } \\ 2 & 0.1-0.5 & 1 & \text { " } \\ 2 & 1-2 & \text { varying } & \text { Salix phylicifolia } \\ 28 & 0.5-3.5 & " & \text { Sprouts of different woody plants. }\end{array}$

${ }^{1}$ No mention is found in literature of the use of chresol for destroying woody plants. In ordinary weed control it has been used since 1930's. 
On the last mentioned plots, sprouts of following plants were growing: Almus incana, Salix phylicifolia, S. caprea, Betula pubescens, B. verrucosa, Populus tremula, and Sorbus aucuparia.

The chemicals used in the experiments, and the concentrations of the solutions ( $\%$ of the active substance) were:

\begin{tabular}{|c|c|c|}
\hline Sodium salt of $2 \mathrm{M}-4 \mathrm{~K}$ (Agroxone, & 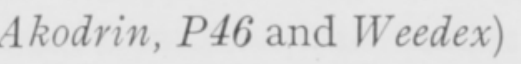 & $0.15-0.4$ \\
\hline Sodium salt of 2,4-D (Hormoxol) & & $0.1-0.4$ \\
\hline Morpholine of 2,4-D (Hormoxol) & & 0.2 \\
\hline riethanolamine of $2,4-\mathrm{D} \ldots \ldots$ & & 0.2 \\
\hline ester of $2,4-\mathrm{D}$ & & $0.1-0.2$ \\
\hline ester of 2,4-D (Weedone) & & $0.1-0.4$ \\
\hline ate (Fekabit) & & $(0.75-7.5)$ \\
\hline$f]$ & $10000(\mathrm{~N})$ & $(0.15-0.75)$ \\
\hline
\end{tabular}

The amount of active substance in Fekabit and Trifoblock is not known, wherefore the tabulation for them gives the concentrations as based on the commercial product.

Manufacturers and distributors of the chemicals are:

Agroxone: Manufacturer Imperial Chemical Industries Ltd., England, Representative in Finland Sören Berner \& Co., Helsinki. - Akodvin: Manufacturer Bauer Products Ltd., London. Representative in Finland S. G. Nieminen Oy, Helsinki. - Hormoxol: Manufacturer and distributor S. G. Nieminen Oy, Helsinki. - P46: Manufacturer Pest Control Ltd., England. - Weedex and Weedone: Manufacturer American Chemical Paint Company, Ambler, Pa. Representative in Finland Oy Trans-Meri Ab, Helsinki. — Triethanolamine of 2,4-D: Manufacturer S. G. Nieminen Oy, Helsinki. — Butyl ester of 2,4-D: Manufacturer J. T. Baker Chemical Co., U.S.A. Representative in Finland S. G. Nieminen Oy, Helsinki. Fekabit: Manufacturer and distributor Elektrokemiallinen Oy, Imatra. - Trifoblock: Manufacturer M. van Waveren $\mathrm{Zn} \mathrm{N}$. V., Holland.

In most of the growth regulators mentioned above, oil was used as wetting agent and solvent. In order to investigate the importance of the wetting agent, sodium salt of 2,4-D was used in a pure aqueous solution, and together with a wetting agent called Panfix (manufacturer S. G. Nieminen Oy, Helsinki). 0,5\% of Panfix was added to the solution.

The spraying experiments were carried out with a Ginge knapsack sprayer. In most experiments such amounts of the solution were used as to make all branches wet. Treatments were carried out at the beginning and in the middle of the summer, in 1948 and 1949. In the former year sodium salt of 2,4-D (Hormoxol) was used in the dates of treatment experiment which was carried out on May 5, June 1, June 7, June 18, and July 10, in the latter year sodium salt of 2M-4K (Agroxone) was used and the dates of application were May 23, May 31, June 8, June 16, June 22, June 30, July 8, July 15, and July 23. In both cases the solution was applied in a concentration of $0.2 \%$. Comparative experiments with regard to different growth regulators and their different concentrations were carried out on June 7, June 22 and, July 10 in 1948, and June 18 in 1949. In addition to ordinary experimental plots, also 


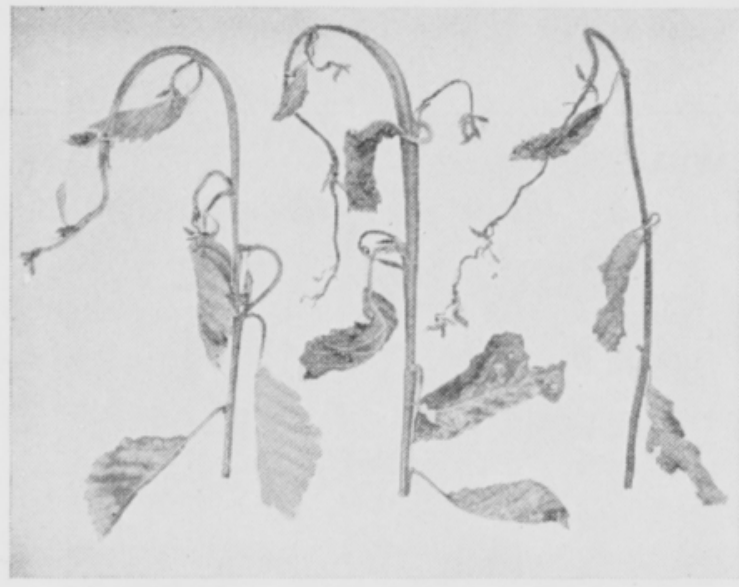

1

2

3

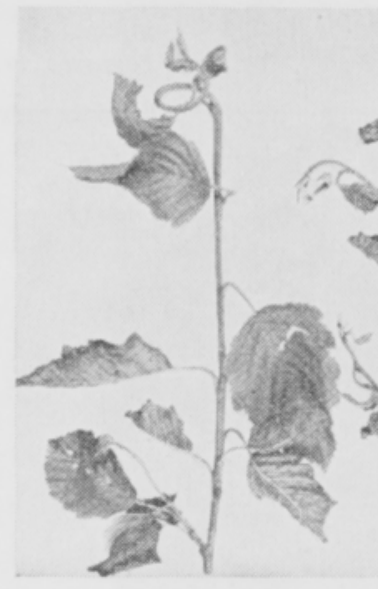

1

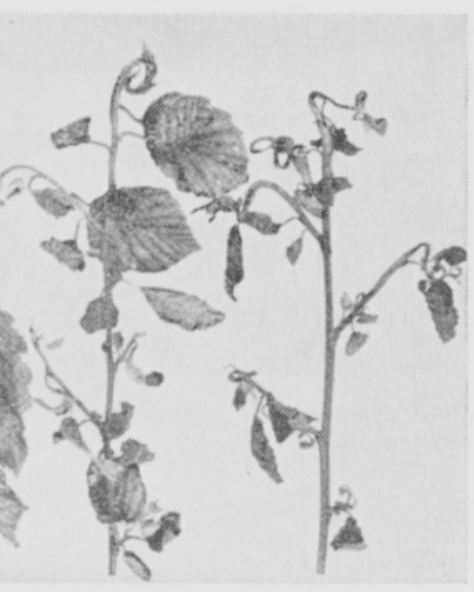

2

37

Figure 1. Branches of alder injured by artificial hormone spray $[0.2 \% 2 M-4 K]$. On the left young, on the right old branches. $1=$ two, $2=$ four, and $3=$ six weeks after treatment.

separate shoots were sprayed in order to determine the effect of different concentrations. Chlorate and chresol were only applied to single sprouts of alder and willow. Sprayings with chlorate were conducted on June 18 and July 7, sprayings with chresol on July 5 and July 10 in 1948.

Owing to treatments with growth regulators the leaves of the sprouts at first became slackened, their tops bent downwards, and finally the plants stiffened in this bent position. Especially the tops of young sprouts increased considerably in height (fig. 1), later also in thickness, when their bark was split longitudinally. Leaves turned brown and died $1 / 2-1$ week after the treatment with ethyl ester of 2,4-D (Weedone), 2 weeks after the application of butyl ester of $2,4-\mathrm{D}$, and $3-5$ weeks after the application of other growth regulators. After this, alder began to develop proliferations under the bark at the bases of stems and branches (fig. 2). If 2,4-D was used in ester form, proliferation was slight. For other woody plants this phenomenon was rare. If chresol was applied leaves lost their green colour within a day, but remained alive for about 2 more weeks. Application of chlorate resulted in death of leaves within $3-6$ days.

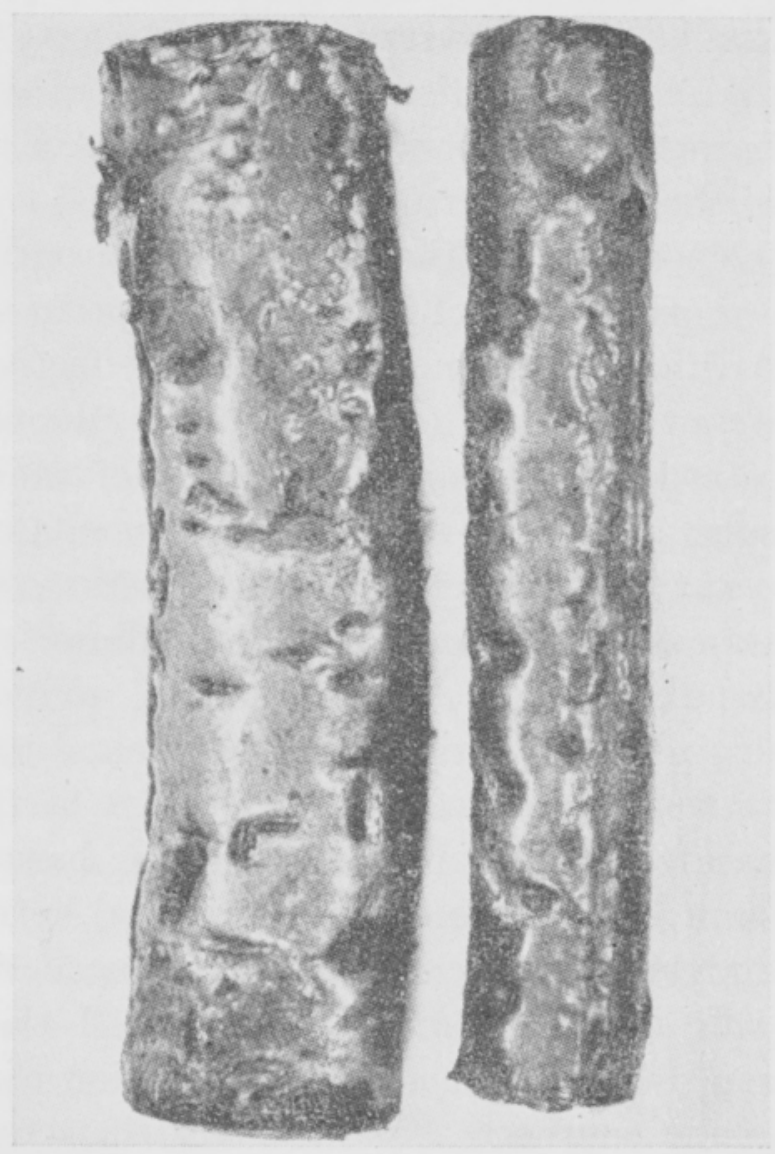

Figure 2. Proliferations due to artificial hormones in the bark of alder 3 monthes after treatment $[0.2 \%$ sodium salt of 2,4-D]. Of the natural size. 
Table 1. The concentrations of solutions needed for killing the foliage of woody plants (percentage of active substance in sprays).

\begin{tabular}{|c|c|c|c|c|c|}
\hline Chemical & $\begin{array}{c}\text { Alder } \\
\text { (Alnus) }\end{array}$ & $\begin{array}{l}\text { Willow } \\
\text { (Salix) }\end{array}$ & $\begin{array}{c}\text { Birch } \\
\text { (Betula) }\end{array}$ & $\begin{array}{l}\text { Mountain ash } \\
\text { (Sorbus) }\end{array}$ & $\begin{array}{c}\text { Aspen } \\
\text { (Populus) }\end{array}$ \\
\hline Ethyl ester of 2,4-D (Weedone) $\ldots .$. & 0.1 & 0.15 & 0.15 & 0.2 & 0.3 \\
\hline Butyl ester of $2,4-D \ldots \ldots \ldots \ldots \ldots$ & 0.15 & 0.15 & 0.15 & 0.2 & - \\
\hline Other artificial hormones $\quad \ldots \ldots \ldots$ & 0.2 & 0.2 & 0.2 & 0.3 & 0.4 \\
\hline Potassium chlorate (Fekabit) $\ldots \ldots \ldots$ & $(6.0)$ & $(7.0)$ & - & - & - \\
\hline Chresol (Trifoblock) ............ & $(0.6)$ & $(0.7)$ & - & - & - \\
\hline
\end{tabular}

The lowest concentrations of different herbicides resulting in death of leaves are given in Table 1.

Alder proved the most susceptible to artificial hormones. Then, in the order of susceptibility, came willow and birch, then mountain ash and aspen. Of different willows Salix caprea was slightly more resistant than Salix phylicifolia. The leaves of aspen were extremely resistant, and it seems that destroying its sprouts by sprayings with artificial hormones is not to be recommended because of high costs. Also Hilli (5) has observed that aspen is fairly resistant, whereas Osvald and ÅBERG (21) have reported it to be very susceptible to artificial hormones. Chlorate and chresol were more effective on alder than on willow. In ester form artificial hormones were more effective than in any other form. The rapid and strong effect of the ethyl ester of 2,4-D (Weedone) is possibly partly due to its oil solvent which seemed to burn the leaves in a short time.

The leaves of young, small sprouts died more readily than those of tall plants. Artificial hormones were most effective at the beginning of summer. If leaves were treated at the end of July results were not satisfactory. Rain and cold weather retarded the effect of artificial hormones. Owing to the quick absorption of these substances, and to the wetting agents of most herbicides rain did not, if it did not occur immediately after application, much decrease the effectiveness of the substance. Experiments with the sodium salt of 2,4-D proved that lack of wetting agent greatly reduced its effectiveness, if it was used at a rainy period. Even during dry periods wetting agent was found to increase the effectiveness of this substance to some extent. Similar opinions of the importance of wetting agent have been expressed already earlier, on the basis of experiments on other plants $(1,22)$. At sunny places the effect of artificial hormones was much quicker than in the shade, and lower concentrations were needed. So in one experiment, the leaves of birch were found to be destroyed by $2 \mathrm{M}-4 \mathrm{~K}$ at a concentration of $0.1 \%$, and those of aspen by $2 \mathrm{M}-4 \mathrm{~K}$ at a concentration of $0.2 \%$, when the plants were growing on a sunny southern slope, whereas the required concentrations at a shady place were $0.2 \%$, and $0.4 \%$ respectively.

Already the first experiments showed that only leaves which had come into contact with the herbicide were killed. Therefore such amounts of the herbicide 


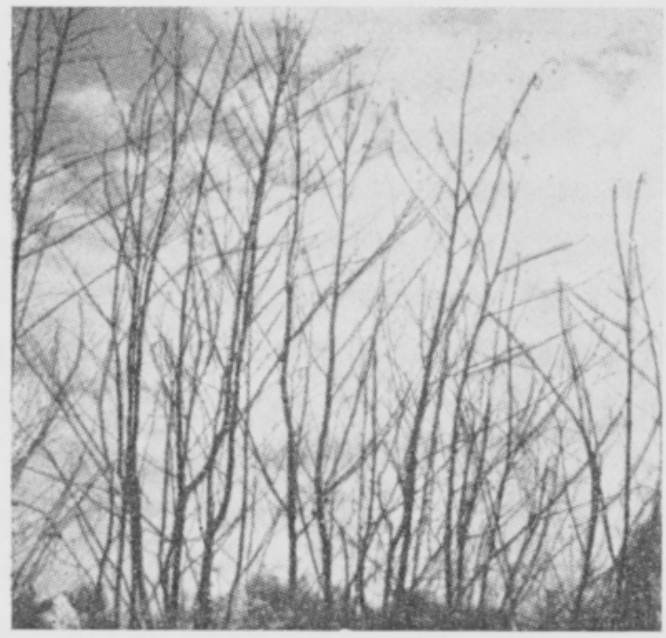

Figure 3. Alders destroyed by artificial hormone sprays a year after treatment $[0.2$ $\%$ morpholine of 2,4-D July 10 1948].

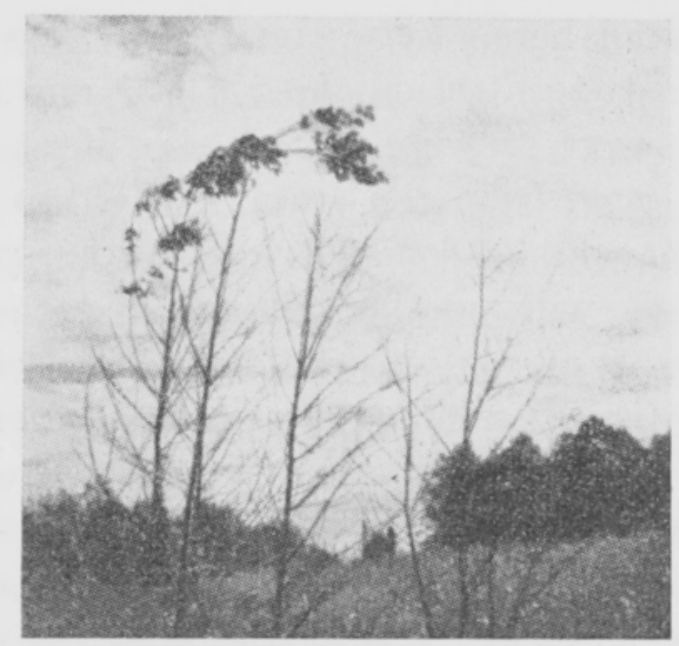

Figure 4. Spraying with artificial hormones must be made so carefully that the leaves of every branch become wet. Tops of too high plants remain alive.

were used in most experiments as to secure the moistening of the leaves of all branches. Artificial hormones and chlorate were translocated from one part of the plant to another to some extent, but translocation was so slight that usually only a few leaves died on untreated branches. (When some branches were sprayed with $1-10 \%$ concentrations, translocation was quicker). Spraying with a short-handled sprayer was not sufficiently effective if sprouts were higher than $2.5 \mathrm{~m}$. Untreated tops remained then alive (fig. 4). In the conducted experiments the used amount of solution, depending on the density and the height of the thicket, was $5-301$. per are $(=500-3000$ l. per ha.). In a dense, $0.5-1.5 \mathrm{~m}$. high thicket the required amount was $12.5-201$. per are (= 1250 - 2000 l. per ha.).

The reported results of the effect of spraying with artificial hormones on the leaves of sprouts and of factors affecting this confirm, on the whole, earlier investigations $(1,4,5,6,12,23,24)$. Usually the figures giving the concentrations of solutions are not very accurate. It is evident that the concentration is to a large extent dependent as well on the amount of the solution used as on circumstances. The amount of solution (1000 1. per ha.) used by Hilli $(5,6)$ is evidently only sufficient for eradication of low and thin thickets.

When leaves were dead, the sprouts treated with chlorate and chresol began to develop new branches with leaves from the axillary buds of the old leaves, and new sprouts from the buds at the base of the stem. On the other hand, sprouts treated with artificial hormones usually showed no signs of regeneration by autumn. Sprouts sprayed earlier in the spring formed an exception in this respect. They developed buds at the base of branches and stems, and these buds developed new sprouts. This occurred with willows if treated between May 23 and June 8, and with alders if treated between May 23 and May 31. Also Rennerfelt (18) warns against too early spraying. Because of the scarcity of material no observations concerning this phenomenon could be made for other species in the experiments 
reported here. Regeneration was also observed after one treatment with $2 \mathrm{M}-4 \mathrm{~K}$ at the concentration of $0.2 \%$ on June 22 in 1948. Only sprouts of alder, $0.1-0.5 \mathrm{~m}$. high, were growing on this experimental area at the time of treatment. They had developed from the stumps of alders cut down in the previous year when their height was 5-6 m. Evidently the sprayed stump sprouts were so small in comparison with mother stumps and their roots that ordinary concentrations and amounts of solutions could not be absorbed through the sprouts into mother stumps in sufficient amounts to prevent regeneration.

In the summer following the treatment, alders sprayed with artificial hormones in 1948 were mostly found to be dead, roots included, with the exception of the above-mentioned cases. Only in rare cases occasional suckers were found. Other species of woody plants proved more difficult to kill. The base of their stem was in some cases still found to be alive in spring, and the buds at the base began to develop into new sprouts in summer. Aspen even developed new suckers. Regeneration was slightest if treatment was not carried out before the end of June or the beginning of July.

Ground vegetation on the experimental areas was chiefly formed by species of Agrostis, Deschampsia, and Calamagrostis. It was not injured by artificial hormones, but chlorate and chresol proved injurious. In the summer of 1949 it was observed that where thickets of alders had been treated in 1948, the treatment resulting in the death of woody plants, grass had acquired a darker green colour and grew more vigorously than the surrounding grass. This was possibly due to the nitrogen released from the dead alders' root nodules.

It may be mentioned in this connection that the first experiment of destroying woody plants by chemical sprays on a large scale was carried out on the estate of Leppävaara, near Helsinki. The experiment was arranged by Mr. $\mathrm{H}$. Av Heurlin, M. A., according to the directions given by Agricultural Research Institute. Spraying was given August 4 in 1948 by a tractor-drawn motor sprayer. The herbicide used was $0.2 \% 2 \mathrm{M}-4 \mathrm{~K}$ (Agroxone). $0.5-3 \mathrm{~m}$. high thicket of alder and willow sprouts, with occasional birches and aspens, was growing on the treated area, about 3 ha. The results were very promising. With the exception of aspen, all above-ground parts of the woody plants were thoroughly destroyed, and so far hardly any regeneration has occurred. Thus we have reason to believe that even the roots of most sprouts were killed.

On the basis of the conducted spraying experiments, it seems that for spraying of woody plants it is advisable to use only such chemicals as destroy leaves and at the same time prevent the development of buds. The results confirm the opinion expressed by THImann (25) that the influence preventing the formation of additional buds in the main shoot is due to the translocation of auxins from the top of the plant. Buds are considerably more susceptible to the growth-inhibiting influence of a large amount of auxins than is the development of the main shoot. If the stem of a woody plant is cut off, translocation of auxins ceases, and additional buds begin to develop. This occurs also if the leaves are destroyed by an ordinary corroding or burning chemical (e.g. chlorate and chresol). If, on the other hand, 
the leaves of a woody plant are sprayed with a large amount of some chemical having similar effects to those of auxins, i.e. artificial hormones, the buds at the base of the stem do not begin to develop though the leaves are dead. Small amounts of artificial hormones namely continue to enter the buds for a long time after the leaves are dead. Translocation of artificial hormones from one part of the plant into another is, however, so slight that they do not kill the leaves on untreated branches. Therefore it is important to do the spraying so effectively that all branches are treated. - A careful spraying of thickets is very difficult. Therefore the result of the treatment must be verified after $2-3$ weeks. The leaves on the branches treated with the herbicide have by this time begun to die, and it is easy to find the untreated branches and spray them again. Spraying with artificial hormones gives the best results, if carried out towards the end of June, or at the beginning of July. It seems that for alder it is possible to prevent the formation of new stem sprouts almost completely by a treatment in one summer, if the sprouts sprayed are not growing on stumps of very big trees. On the other hand, willow, birch, mountain ash, and aspen develop some new stem sprouts in the next summer, aspen also suckers. The formation of suckers is not entirely unknown with alder, either. Evidently artificial hormones sprayed on leaves are only able to affect the parts of roots next to stumps, and long, lateral branches of roots may remain alive. For other plants, a similar result was earlier obtained by KEPHART (9). - If knapsack sprayers are used, spraying can only be applied to sprouts and suckers which are not higher than $1.5 \mathrm{~m}$.

\section{Absorption experiments.}

Woody plants on fields and pastures often attain such heights as to render their eradication with spraying inadvisable. For the destruction of such thickets many methods have been suggested earlier. According to these, the chemical is applied to the stem or to the stump of the plant $(1,2,4,7,23)$. Preliminary absorption experiments were carried out at the Department of Plant Husbandry of Agricultural Research Institute. Alders, $4-6 \mathrm{~m}$. high, and $2-4$ inches thick were chiefly used as experimental plants. One of the lowest branches of the tree was cut at a suitable point, and the remaining branch stub was put in a bottle filled with a solution of high concentration of artificial hormones (fig. 9). The bottle was fixed to the branch with an iron wire, and remained hanging. Treatments were conducted in June, July, and August in 1948.

Herbicide entered different parts of the plant quickly through the branch. Leaves to which the substance was transported became brown immediately and died. The above-ground parts of most treated alders were completely destroyed. A year after the treatment it seemed as if even their roots had been killed. The poisonous effect of artificial hormones often spread to near-by alders, too, sometimes even to other species of woody plants. This appeared $1-2$ months after the treatment, and the phenomenon continued the next summer. Translocation of artificial hormones from one woody plant to another probably occurred in the following 


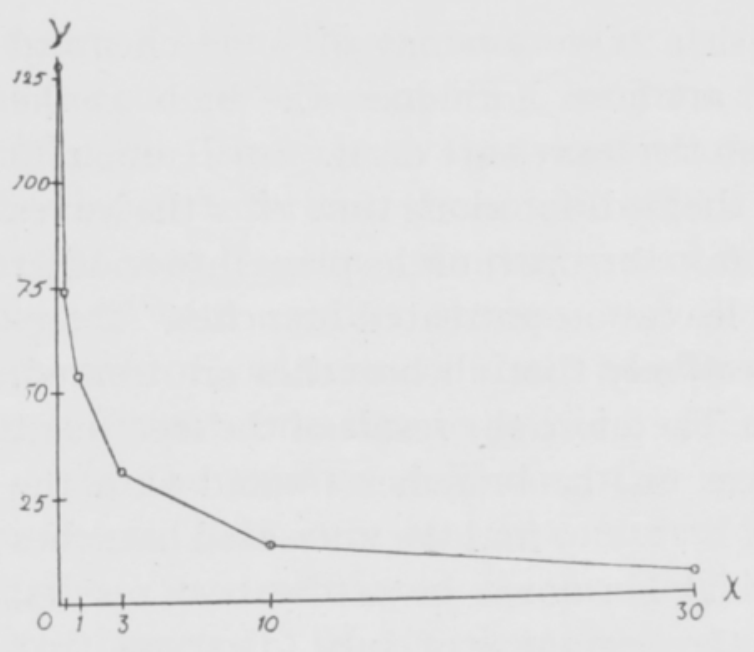

Figure 5. A mout of morpholine solutions of 2,4-D at different concentrations absorbed during the first day $x=$ concentration of the solution $[\%] ; y=$ absorption of the solution [g.]. Alder.

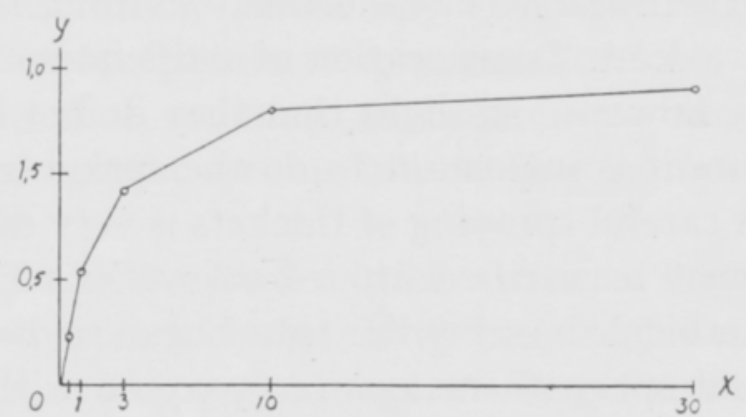

Figure 6. Use of active substance for different concentrations of morpholine solutions of 2,4-D during the first day. $x=$ concentration of the solution $[\%] ; y=$ use of active substance [g.]. Alder.

ways: 1) through roots of the treated alder to other trees whose roots were connected with these, 2) if branches of near-by woody plants touched those of treated alders, 3) if the herbicide crystallized on the leaves of a tall alder was washed by rain and fell on the leaves of smaller plants, and 4) by means of smell. This means of translocation was not often found until the next spring when the buds on some woody plants growing near the treated alders remained unopened or developed deformed leaves. Possibly the smell of the herbicide affected the buds which had developed in the previous summer, since buds are very susceptible to growth regulators (25). Even earlier it was known that the esters of 2,4-D are so volatile as to cause destruction of plants while evaporating from an open dish in a closed greenhouse $(20)$.

In táller trees absorption occurred more slowly than in smaller ones. Very tall alders could not be completely destroyed by this method. The result was always more certain if the absorbing branch was at a low level on the stem. A similar opinion with regard to the point of application of the chemical has been expressed already earlier $(2,4,7)$. Entrance was easier through short and thick branches than through long and thin ones. Therefore it was advisable to cut the branch so near the stem as possible. If the absorbing branch was not cut, but its top with leaves was put in a bottle filled with a solution of herbicide, absorption occurred rather slowly. Small alders were, however, killed even by this method.

For other species of woody plants the effect of artificial hormones absorbed through branches was slighter than for alder. For willow the influence was fairly strong, but as willow usually grows in shrubs, only part of its branches were killed if absorption only occurred through one plant. As to mountain ash, birch, and aspen, only very young, $1-2 \mathrm{~m}$. high plants were killed by this method. ${ }^{1}$

1 With view of drying trees out on the stumps for industries the method was also experimented on spruce, Picea excelsa (Lam.) Link. Absorption proved weak. 


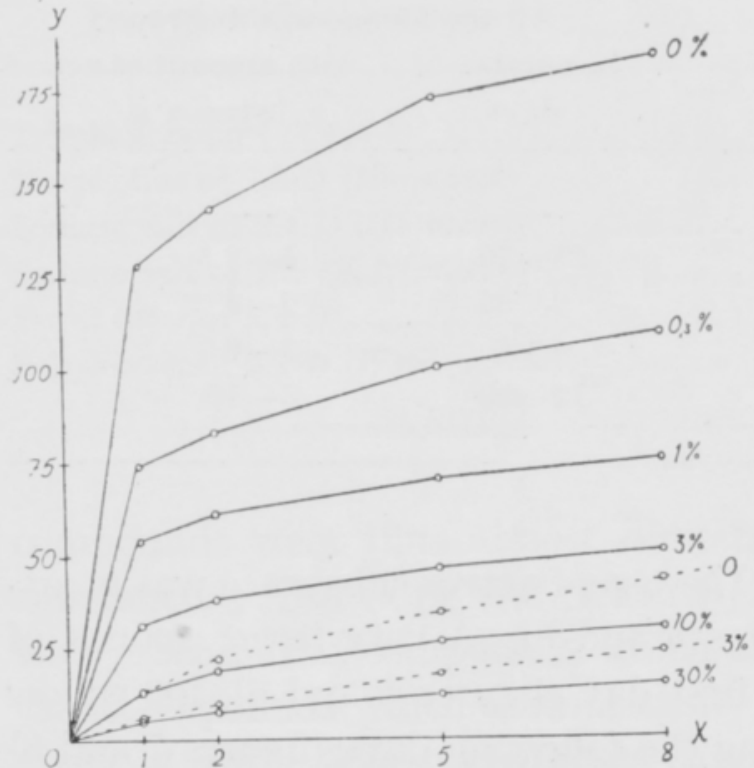

Figure $\%$. Amount of morpholine solutions of $2,4-D$ at different concentrations absorbed during $1-8$ days. $x=$ concentration of the solution $[\%]$; $Y=$ absorption of the solution [g.]. -...- willow.

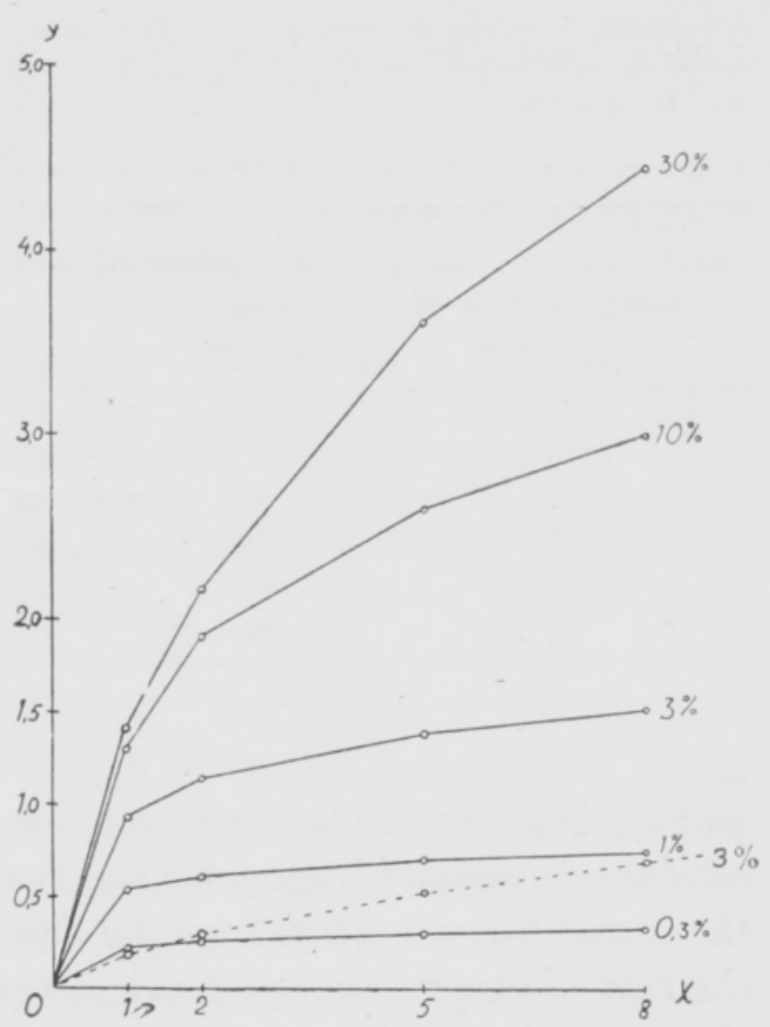

Figure 8. Use of active substance for different concentrations of morpholine solution of 2,4-D during $1-8$ days. $x=$ concentration of the solution $[\%]$; $y^{\circ}=$ use of active substance $[\mathrm{g} \cdot]$ _ alder;

The method described above was also used in some experiments with chlorate and chresol. They entered alders fairly well, but sometimes leaves on some branches remained alive. Detailed investigations with these chemicals were not carried out.

When it had become evident that some chemicals can be effectively absorbed by woody plants and be transported to different parts of the plant, the phenomenon was subjected to more detailed investigations in 1949. Several experiments were carried out in July and August, and these experiments elucidate the speed of absorption of different solutions, their effect, and manner of translocation in different parts of the woody plant.

1. Rate of absorption and effect of morpholine solutions of 2,4-D at different concentrations. Trees of similar size - if possible - were selected for this experiment: $5 \mathrm{~m}$. high alders and willows. Concentrations of $0.3,1,3,10$, and $30 \%$ were experimented on alders, concentrations of $3 \%$ on willows. By way of comparison, also pure water was applied to each species of trees. The lowest branch of the plant was used as an absorbing plant. The bottles were closed with wax. Bottles were weighed after $1,2,5$, and 8 days in order to find out how much liquid had been used. Results for each solution as averages from 5 plants are given in figures $5-8$.

The waaker was the used solution, the more of it was absorbed (figures 5 
Table 2. Speed of the effect of morpholine solutions of 2,4-D at different concentrations on $5 \mathrm{~m}$. high alders, and the amount of active substance used for killing the trees. The soluiions were applied to alders through cut branches.

\begin{tabular}{ccccc}
\hline \hline $\begin{array}{c}\text { Concentration of } \\
\text { solution } \%\end{array}$ & $\begin{array}{c}\text { Percentage of dead leaves } \\
\text { after } \\
5 \text { days }\end{array}$ & $\begin{array}{c}\text { After } \\
15 \text { days }\end{array}$ & $\begin{array}{c}\text { All the foliage was destroyed } \\
\text { in number of } \\
\text { days }\end{array}$ & $\begin{array}{c}\text { with amount of active } \\
\text { substance g. }\end{array}$ \\
\hline 0.3 & + & 5 & - & - \\
1 & 50 & 60 & $25-70$ & $1-2.5$ \\
3 & 70 & 80 & $8-50$ & $2-4$ \\
10 & 60 & 90 & $12-40$ & $3-6$ \\
30 & 50 & 90 & & $5-10$ \\
\hline
\end{tabular}

and 7). Pure water was absorbed best of all. The use of active substance was greatest for solutions of high concentrations (figures 6 and 8 ). A very large amount of the liquid was absorbed by alder during the first day (figures 5 and 6 ), for willow the rate of absorption was much lower. During the following days (figures 7 and 8) the rate of absorption was only a fraction of that of the first day for alder, for willow there was only a slight reduction in the rate of absorption. For alder slower absorption was found to be chiefly due to the substances formed on the cut surface. The rate of absorption was quickened to the original for some hours if a piece was cut off from the branch stub, the bottle was washed, and filled with new liquid. At a later stage death and withering of the absorbing branch caused retardation in absorption.

The speed of the effect of different concentrations of morpholine solutions of 2,4-D on alder and the amount of active substance required for killing of alders are given in Table 2. At first the concentration of $3 \%$ proved the most effective. Later the effect of $3-30 \%$ concentrations was almost the same. It is obvious that at a concentration of $3 \%$ the solution of artificial hormones, when transported with a large amount of water, at first reaches different parts of the plant more quickly than solutions of higher concentrations. The effect of $1 \%$ concentration is markedly lower than that of the above-mentioned solutions, and $0.3 \%$ concentrations did not result in death of alders at all. The amount of active substance required for killing alders varied from 1 to $10 \mathrm{~g}$., and it was largest for high concentrations. For reasons easily recognizable, the figures cannot be quite exact, for it is impossible to determine accurately when the tree has absorbed so much poison as to make death inevitable.

2. Speed of absorption and effect of different types of artificial hormones. The experiment was carried out with $5 \mathrm{~m}$. high alders in the same manner as the first experiment. Concentrations of $3 \%$ were used for absorption. Bottles were weighed after 1 day. The results are given in Table 3. Triethanolamine and morpholine of 2,4-D were absorbed best and were the most effective, esters were the least effective and absorbed with difficulty. The effect and rate of absorption of 2,4-D 
Table 3. The amount of different types of artificial hormones at $3 \%$ concentration absorbed during the first day by $5 \mathrm{~m}$. high alders, and the speed of the effect of the solutions. The solutions were applied to alders through cut branches.

Type of artificial hormone
Absorption of solution during the first day g. after 5 days after 15 days
Percentage of dead leaves
Triethanolamine of $2,4-\mathrm{D}$

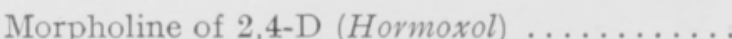

Sodium salt of 2,4-D (Hormoxol) $\ldots \ldots \ldots$.

Sodium salt of $2 \mathrm{M}-4 \mathrm{~K}$ (Agroxone) $\ldots \ldots \ldots$.

Butyl ester of $2,4-\mathrm{D} \ldots \ldots \ldots \ldots \ldots \ldots \ldots$

Ethyl ester of 2,4-D (Weedone) $\ldots \ldots \ldots \ldots$

$$
\begin{gathered}
35 \pm 3.7 \\
31 \pm 4.2 \\
26 \pm 2.6 \\
(24 \pm 2.3) \\
(20 \pm 2.1) \\
(1.5 \pm 0.2)
\end{gathered}
$$

compounds were thus almost directly proportional to the water-solubility of the substance. ${ }^{1}$ Also Cope and Spaeth (2) suggested on the basis of their experiments with arsenic that compounds which are easily dissolved in water are more effective than compounds which are not easily dissolved in water. The figures of absorption given in Table 3 in parentheses cannot be compared with other figures. In these cases the artificial hormone and the solvent or wetting agent in them was wholly or partly separated from water, and became turbid or rose up to the surface. Thus the composition of the solution was different from that of the original solution.

The effect of some wetting agents and solvents on the absorption was investigated in experiments made with pure water and aqueous solution of the sodium salt of 2,4-D. It was observed that some oil substances which are insoluble in water and form emulsions may altogether prevent absorption. On the other hand, absorption is only slightly retarded by some water-soluble oils. In this experiment, triethanolamine and sodium salt of 2,4-D were applied in pure aqueous solutions. Morpholine of 2,4-D and $2 \mathrm{M}-4 \mathrm{~K}$ contained water-soluble oil, whereas the ethyl and butyl esters of 2,4-D contained waterinsoluble oil which formed emulsions in water. The oil in the ethyl ester formed a fairly permanent emulsion with water, and therefore no absorption occurred. On the other hand, the oil in the butyl ester was fairly quickly detached from water, as was the substance itself, and in this case some pure water was absorbed by the plant.

3. On translocation of liquids in different parts of woody plants. $5 \mathrm{~m}$. high alders were used as experimental plants, from which a piece of bark and phloem (and also $1-2 \mathrm{~mm}$. of wood) was removed above or below the absorbing branch, as indicated by fig. $9(a)$. Part of the experimental trees were cut above the absorbing branch $(b)$. The experiment was made with pure water and the morpholine of $2,4-\mathrm{D}$ at a concentration of $3 \%$. In the first case, the lowest branch of the tree was used as the absorbing branch; in the second case, the second lowest branch. Each treatment was made with 5 replicates, as in the other absorption experiments.

1 About $40 \%$ of the triethanolamine of 2,4-D is soluble in water, $50 \%$ of morpholine, and $4 \%$ of sodium salt, whereas esters are water-insoluble. In shops these are sold in oil solutions of high concentrations forming an emulsion if mixed with water. For simplicity, in this paper the name solution is also used for such emulsions. 


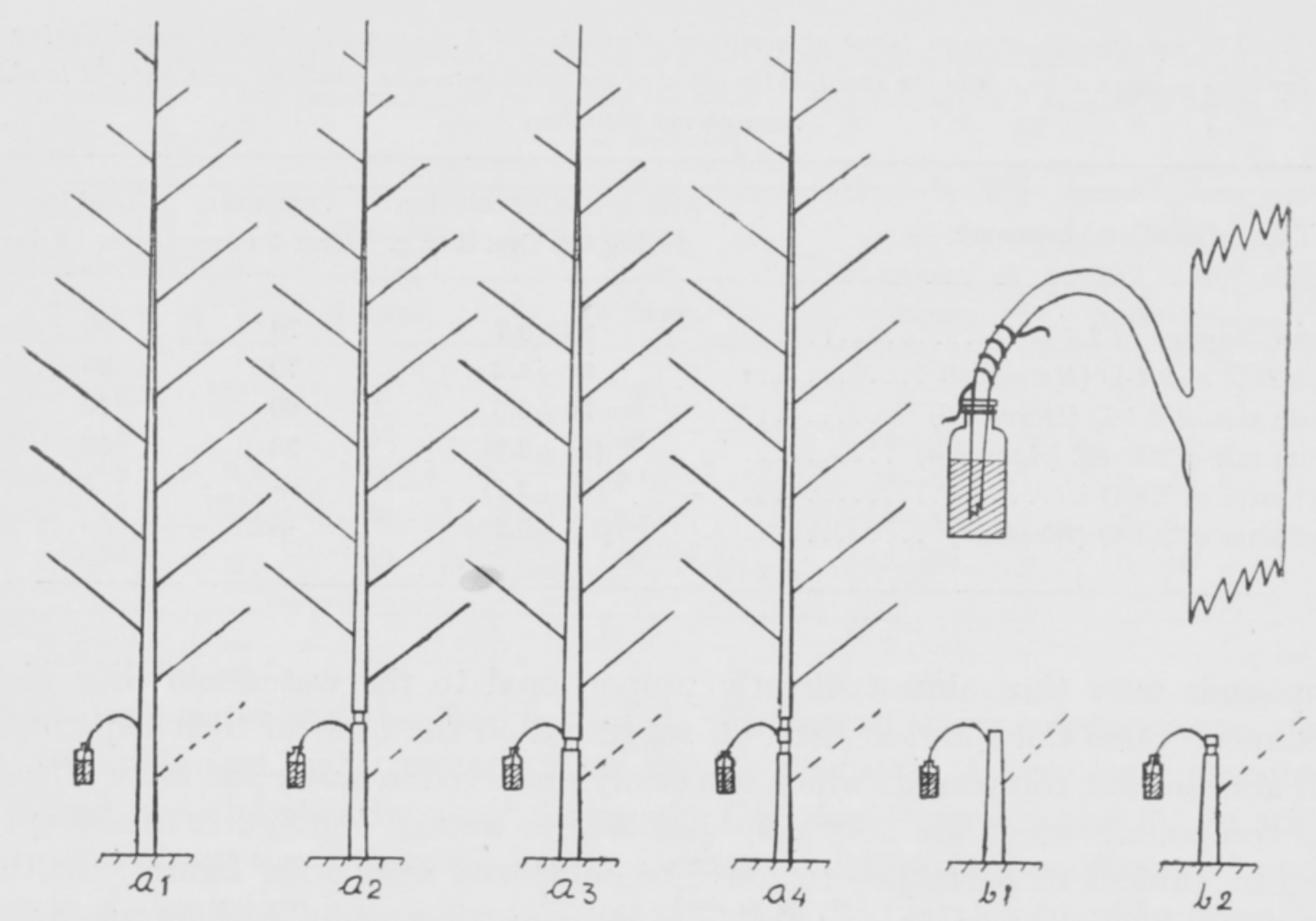

Figure 9. The explanation on the text.

The amount of pure water (g.) absorbed during the first day by the experimental plants mentioned in fig. 9 is given in the following tabulation:

$$
\begin{array}{llll}
a_{1}{ }^{\prime} & 135 \pm 3,1 & a_{4} & 136 \pm 8,1 \\
a_{2} & 142 \pm 6,7 & b_{1} & 121 \pm 6,8 \\
a_{3} & 132 \pm 4,8 & b_{2} & 123 \pm 7,2
\end{array}
$$

The removal of bark and phloem did not retard absorption. It cannot be certainly concluded, either, whether cutting of the stem above the absorbing branch in any way affected the rate of absorption. For the last mentioned experimental plants the absorption figures were slightly lower, but differences are within the range of errors. It may be mentioned that in this experiment, as in the earlier experiments with pure water, absorption was so vigorous that a vacuum was formed in the bottle, unless air penetrade into the bottle through a hole made in the wax round the neck of the bottle.

The amount of the solution of artificial hormones (3\% morpholine of 2,4-D) absorbed was not weighed in this experiment. Leaves turned brown immediately after the substance had entered them, so that it was possible to make observations on the translocation of the solution. Removal of bark and phloem did not prevent translocation. In treatment $a$ the compound was first transported upwards, and it killed first the leaves on the branches nearest to light, i.e. the leaves on the highest branches and on the south side. Also Hamner and Tukey (4) observed that the growth regulator absorbed by the stem moved first upwards. Lateral 


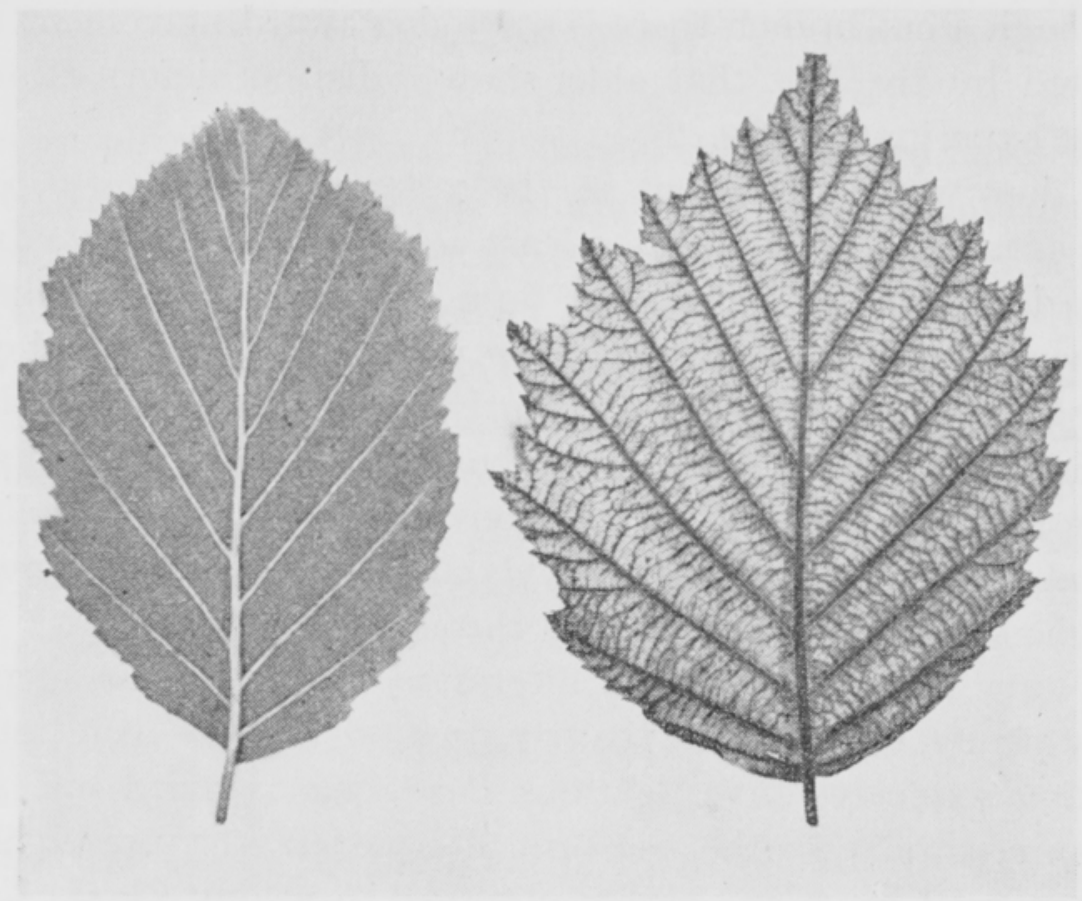

Figure 10. Translocation of artificial hormones absorbed through a branch in petioles. Leaf of the absorbing branch of alder 6 hours after beginning of treatment. On the left: untreated; on the right: treated with $3 . \%$ morpholine of 2,4-D. Petioles have turned brown.

movement occurred slightly more slowly than upward movement. All branches above the absorbing branch died within 25 days, at the latest. When they were completely dry, which took $1-2$ months, the compound also began to move downwards, though slowly, killing the leaves on the branch below the absorbing branch. In treatment $b$ the compound began to travel downwards at once, killing the leaves on the branch below the absorbing branch within $1-5$ days.

In leaves the compound absorbed through the branch moved first through petioles which turned brown (fig. 10). Later the phenomenon was no longer detectable. Owing to retarded absorption the leaf blade evidently changes colour at the same rate as the petioles.

Absorption of liquids was also investigated on stumps of alders. A hole was made vertically downwards in the xylem, and filled with growth regulator. Absorption was extremely vigorous, so that the falling of the liquid surface in the hole could be observed with bare eyes. Pure water was absorbed slightly faster than hormone solutions. Also water-insoluble artificial hormones (esters) were absorbed, though a little more slowly than water-soluble hormones.

The experiments show that in alder the artificial hormones and water absorbed through a cut branch are chiefly transported to different parts of the plant in the xylem. Mitchell and Brown (19), and Weaver and De Rose (26) suggested that hormone applied to the leaves of the plant is transported downwards in the living tissues, mainly in phloem and parenchyma cells, with organic food materials. If applied to root system of the plant it is carried upwards in the dead stem tissues in the transpiration stream of the xylem. It is evident that even at 
absorption through a cut branch there is some downward movement in the phloem. This is indicated by the fact that alder showed distinct deformations in the bark (as in spraying experiments; fig. 2).

In alder, downward movement in the xylem may evidently occur at almost the same rate as upward movement, at least in July, and August. In the xylem of standing trees downward movement of liquids, however, is mostly prevented by the transpiration stream at this time of the year. In the reported experiment the compound travelled easily upwards, evidently carried in the transpiration stream, but downwards only after all the leaves above the absorbing plant were dead and completely dry $(a)$. If the stem was cut above the absorbing branch $(b)$ transpiration ceased and the compound immediately began to travel downwards. This occurred also if the substance was absorbed through a stump.

Scientists have already long been interested in phenomena of pressure in the stems of woody plants, especially in positive pressure and the secretion of sap caused by it, and many extensive investigations have been carried out. (KRAMER, 10). Negative pressure, similar to the pressure observed in the present investigations, and absorption caused by it was earlier observed in woody plants by MACDougaL $(13,14,15)$, and James and Baker (8). The strength of the pressure was largely dependent on species of plant, season of year, time of day, weather conditions, and other growth factors.

The conducted absorption experiments seem to indicate that if high sprouts are eradicated it is best to apply the chemical to the stumps of cut sprouts. The same applies to eradication of tall trees and shrubs. If the substance is applied to the stump it is easily transported towards the roots 'eat ast in July and August. Thus it is not necessary to fight against the transpiration stream and to waste the substance for killing the large mass of plants formed by the above-ground parts of tall trees. According to Ikenberry, Bruce, and Curry (7) stumps can be easily killed by treating them with arsenic, chlorate, or Diesel oil. On the other hand, Cope and Spaeth (2), and Rennerfelt (23) report, on the basis of experiments with arsenic, that a chemical applied to the stump is not so effective as a chemical applied to the base of a standing tree. As the conducted spraying experiments seem to indicate that artificial hormones prevent the formation of buds more effectively than other chemicals, it may be assumed that these substances may give satisfactory results in spite of the cutting of the stem. As was mentioned at the beginning, in U.S.A. esters of 2,4-D have been applied to the cut surface of stumps (1). Detailed information on the results is not available. The types of esters hitherto used for weed control are insoluble in water, and therefore their translocation into different parts of the plants is difficult. So it would be advisable to investigate whether water-soluble compounds could secure better results in this respect. Detailed experiments are necessary to elucidate the usefulness of this method. 


\section{Treatment of soil.}

The poisonous effect of artificial hormones, chlorate, and chresol from the soil was investigated in 1948 by applying solutions of these chemicals to the roots of $2 \mathrm{~m}$. high alders. The experimental area was located on clay soil. Treatment was given July 7 . The poisonous effect of the chemicals from the soil proved so slight as to render this method of eradicating thickets inadvisable. $50-150 \mathrm{~g}$. of chlorate per $\mathrm{m}^{2}$ (Fekabit in $5 \%$ solution) was required for killing alders, and $3-5$ g. of artificial hormones per $\mathrm{m}^{2}$ (the sodium salt of 2,4-D in $2 \%$ solution). Application of chresol did not result in death of alders. These results confirm the investigations of as well Ikenberry, Bruce, and Curry (7) as Hilli (5).

\section{Sum mary.}

On the initiative of the Department of Plant Husbandry of Agricultural Research Institute, experiments for destroying woody plants on fields and pastures were conducted in 1948 - 1949 with the following chemicals: Artificial hormones (sodium salt of 2,4-D, morpholine of 2,4-D, triethanolamine of 2,4-D, ethyl ester of 2,4-D, butyl ester of 2,4-D, and sodium salt of $2 \mathrm{M}-4 \mathrm{~K})$, potassium chlorate, and ammonium salt of dinitro-ortochresol. The substances were applied in aqueous solutions, or as emulsions. Three different methods were used: spray application to foliage, absorption through a cut branch, and application to soil. The following thicket-forming woody plants, common in Finland, were investigated: grey alder, Alnus incana (L.) Willd., willow, Salix sp., birch, Betula sp., mountain ash, Sorbus aucuparia L., and aspen, Populus tremula L.

Following conclusions have been drawn from the experiments:

It is possible, and, probably with the exception of aspen, even advisable to destroy small sprouts, $0.5-1.5 \mathrm{~m}$. in height, of these woody plants by spraying their foliage with artificial hormones early in summer, especially if mechanical clearing machines cannot be used. Of the experimented substances, esters of 2,4-D proved the most effective in spray applications, but satisfactory results were even secured with other artificial hormones. For different species of woody plants the necessary concentration of the solution varies from 0.1 to $0.4 \%$ of the active substance (p. 6). For dense thickets, $0.5-1.5 \mathrm{~m}$. in height, the amount of solution used was 1250-2000 l. per ha., applied by means of knapsack type of pressure sprayers. All branches must be sprayed. It is difficult to make the treatment effective enough, if only one application is made. Therefore it is important to conduct a new control spraying after $2-3$ weeks. Treatment is most effective, if given in warm, sunny weather. The best results are secured with spraying towards the end of June or at the beginning of July. If treated early in spring, many new sprouts develop on stems and branches; if treated late in summer, artificial hormones do not kill leaves effectively enough. The leaves of young sprouts and suckers die more readily than those of old tall trees and shrubs. It is possible to 
prevent the regeneration of alder almost completely by sprayings in one summer, if sprouts do not grow from the stumps of very tall trees. Willow, birch, mountain ash, and aspen often show slight regeneration in the following summer. The results obtained with sprayings with artificial hormones confirm - with slight exceptions - the results of earlier investigations $(1,4,5,6,12,23,24)$.

It is possible to kill the leaves of sprouts by sprayings with chlorate and chresol, but such treatment does not prevent the development of new sprouts.

Aqueous solutions of the investigated types of artificial hormones can be effectively applied to alders through a cut branch (fig. 9). Water-insoluble artificial hormones cannot be thus absorbed. Solutions of low concentrations are absorbed more easily than those of high concentrations. The amount of active substance used, however, is for the latter type greater than for the former. Relatively tall alders, and their roots, can thus be killed. But tall willows, birches, mountain ashes, and aspens are not killed, if the substance is applied to one branch only. The necessary amount of substance is even for alder so great that this method cannot be recommended for general practice. Solutions absorbed through cut branches are chiefly transported to different parts of the plant in the xylem. Because of the transpiration stream their translocation downwards in the xylem is very difficult. If transpiration stream, however, is prevented by cutting the stem above the absorbing branch, the substance travels vigorously towards the roots, at least in July and August. Based on this, it has been suggested that high thickets of sprouts (and suckers) as well as tall trees and shrubs, from whose stumps thickets develop, should be destroyed by applying artificial hormones to the stumps of cut plants. Thus it would not be necessary to pay attention to the transpiration stream, and active substance need not be wasted for destroying the above-ground parts of these plants. Possibilities of using this method must be further investigated.

Also solutions of chlorate and chresol can be absorbed through cut branches into alders. It remains to be investigated whether this absorption is effective.

Applications of the above-mentioned artificial hormones, chlorate, and chresol to the soil do not secure satisfactory results with regard to destruction of woody plants, at reasonable costs.

\section{REFERENCES .}

(1) Avery, George S. Jr. \& Johnson, Elisabeth B. 1947. Hormones and horticulture, p. 215-235 New York and London.

(2) Cope, Joshua A. \& Spaeth, J. Nelson 1931. The Killing of Trees with Sodium Arsenite. J. of Forestry, 29, p. $775-783$.

(3) Hale, J. D. 1947. A Summary of Experiments on Chemical Barking of Trees. A paper prepared for the Annual Meeting of the Woodlands Section of the Canadian Pulp and Paper Association, Ottava. Type written. 
(4) Hamner, C. J. \& Tukey, H. B. 1946. Herbicidal action of 2,4-dichlorophenoxyacetic acid on several shrubs, vines and trees. Bot. Gaz., 10\%, p. $379-385$.

(5) Hillı, A. 1948. Leppien ja pajujen hävittämisestä viljelyksiltä. Koetoiminta ja käytäntö, 5 , p. 41-42. Helsinki.

(6) —- 1949. Metsäkasvit ja hormonikäsittely. Metsätaloudellinen Aikakauslehti, 66, p. 411-414. Helsinki.

(7) Ikenberry, G. J., Bruce, H. D. \& Curry, John R. 1938. Experiments with Chemicals in Killing Vegetation Firebreaks. J. of Forestry, 36, p. 507-515.

(8) James, W. O. \& Baker, H. 1933. Sap pressure and the movements of sap. New Phytologist, 32 , p. $317-343$.

(9) Kephart, L. W. 1946. 2,4-D, New Killer for Weeds. Succesfull Farming, 44. Ref. ÅBerg \& DENWARD, p. $248-249$.

(10) Kramer, Paul J. 1949. Plant and Soil Water Relationships, p. 166-188. New York, Totonto and London.

(11) Lindfors, T. H. 1933. Utrotning av berberisbusken. Statens Växtskyddsanst., Flygblad 5 , p. $1-5$. Stockholm.

(12) Leonard, O. A. \& Herzel, F. H. 1945. The hormone weed killer - 2,4-D. Mississippi Farm Research, 8, 10, p. 2. Ref. Avery \& Johnson.

(13) MacDougal, D. T. 1925. Absorption and exudation pressures of sap in plants. Proc. Am. Phil. Soc., 64 , p. $102-130$.

(14) — 1926. The hydrostatic system of trees. Carnegie Inst. Wash. Pub., 373.

(15) - - Overton, J. B. \& Smith, G. M. 1929. The hydrostatic-pneumatic system of certain trees: movements of liquids and gases. Ibid. Pub., 397.

(16) McIntosh, D. C. 1948. Chemical Treatment of Trees. Reprinted from Pulp and Paper Magazine of Canada, June issue.

(17) - 1949. Treatment of Trees with Chemicals. Preliminary Results of Chemical Treatment Experiments Gonducted in co-operation with Marathon Paper Mills of Canada Ltd., at Stevens, Ontario. Type written.

(18) — \& Hale, J. D. 1949. Effect of Chemical Treatment of Trees on Ease of Peeling. Results of Studies made in co-operation with the Marathon Paper Mills of Canada Ltd., at Stevens, Ontario. Type written.

(19) Mitchell, John W. \& Brown, James W. 1946. Movement of 2,4-dichlorophenoxyacetic acid stimulus and its relation to translocation of organic focd materials in plants. Bot. Gaz., 107 , p. $393-407$.

(20) Osvald, Hugo 1947. Hormonderivat i kampen mot ogräs. Växtodling, 2, p. 239. Uppsala.

(21) -—— ¿ \&Berg, Ewert 1949. Kampen mot ogräset. Ibid., 4, p. 116-117.

(22) PaAtela, Juhani 1949. Artificial hormones and weed control in oil flax cultivations. Valt. maatalouskoet. julk., 131 , p. $40-43$.

(23) Rennerfelt, ERIK 1948. Försök att med kemiska medel förhindra stubbskottsbildning hos björk på hyggen. Norrland skogvårdsförbunds tidsskrift, p. 119-139.

(24) —- \& Fransson, P. 1949. Bekämpning av björksly med fenoxiättiksyrederivat. Skogen, 36 , p. 177. Stockholm.

(25) Thimann, K. V. 1946. Plant hormones and the analysis of growth. Currents in biochemical research, ed. D. E. Green, p. 321-323. New York.

(26) Weaver, Robert J. \& De Rose, H. Robert 1946. Absorption and translocation of 2,4-dichlorophenoxyacetic acid. Bot. Gaz., 107, p. 509-521.

(27) Åberg, Ewert \& Denward, Thore 1947. Hormonderivat i kampen mot ogräs. Växtodling, 2, p. 248-249. Uppsala. 
SELOST US.

\title{
VESAKKOJEN HÄVITTÄMISESTÄ KEMIKAALEILLA PELTOVILJELYKSILTÄ JA LAITUMILTA.
}

\author{
JaAkкo Mukula.
}

\section{Maatalouskoelaitoksen kasvinviljelysosasto, Tikkurila.}

Puuvartisista kasveista saattavat sellaiset puut ja pensaat, joilla on kyky lisääntyä kasvullisesti, esiintyä peltoviljelyksillä ja laitumilla haitallisina »rikkaruohoina». Kasvullinen lisääntyminen tapahtuu näillä kasveilla varren tyviosan tai juurien silmuista, joista kehittyy versoja. Varren tyviosasta kasvavia versoja nimitetään runko- tai kantovesoiksi, juurista kasvavia juurivesoiksi. Varsinkin ensiksi mainitut muodostavat usein tiheitä kasvustoja, vesakkoja.

Viime vuosikymmeninä on ryhdytty käyttämään vesakkojen hävittämiseen kemikaaleja. Käsittely voidaan tällöin kohdistaa lehtiin, runkoihin, kantoihin tai maahan. Useiden tutkijoiden mukaan arsenikkipitoiset kemikaalit ovat tehokkaimpia ja samalla halvimpia. Arsenikin myrkyllisyys rajoittaa kuitenkin niiden käyttöä, kun taas useimpien muiden tehokkaiksi osoittautuneiden kemikaalien käytön yleistymistä estää korkea ainekustannus. Viime vuosina on tekohormoneihin kiinnitetty suuria toiveita.

Maatalouskoelaitoksen kasvinviljelysosaston toimesta on suoritettu vesakkojen hävittämiskokeita vuosina 1948 ja 1949 seuraavilla kemikaaleilla: tekohormonit (2,4-D:n natriumsuola, 2,4-D:n morfoliini, 2,4-D:n trietanolamiini, 2,4-D:n etyliesteri, 2,4-D:n butyliesteri ja 2M-4K:n natriumsuola), kaliumkloraatti ja dinitro-ortokresolin ammoniumsuola. Aineita on käytetty vesiliuoksina tai emulsioina, Käsittelyä on kokeiltu kolmella erilaisella menettelytavalla: ruiskuttamalla kemikaalilehdille, imeyttämällä aine kasviin katkaistusta oksasta tai levittämällä maahan. Tutkimukset ovat kohdistuneet seuraaviin Suomessa yleisiin, vesakkoja muodostaviin puukasvilajeihin: harmaa leppä, Alnus incana (L.) Willd., paju, Salix sp., koivu, Betula sp., pihlaja, Sorbus aucuparia L. ja haapa, Populus tremula L.

Suoritettujen kokeiden perusteella on tehty seuraavat päätelmät:

Kokeiltujen puukasvilajien vesojen hävittäminen ruiskuttamalla alkukesällä niiden lehdille tekohormonia on mahdollista. Menetelmä muodostunee kannattavaksi (luultavasti haapaa lukuunottamatta), ainakin siellä missä koneellisia raivausvälineitä ei voida käyttää. Edulliseen tulokseen voidaan kuitenkin päästä vain silloin, kun vesat ovat matalakasvuisia, 0.5-1.5 m:n korkuisia. Kokeilluista aineista tehoavat lehdille ruiskutettuna parhaiten 2,4-D:n esterit, mutta muillakin tekohormonityypeillä päästään tyydyttäviin tuloksiin. Eri puulajeilla eri tekohormonityyppejä käytettäessä vaihtelee sopiva liuosväkevyys $0.1-0.4 \%$ tehoavaa ainetta (s. 6). Liuosta kuluu vesakon ollessa tiheää, $0.5-1.5 \mathrm{~m}: \mathrm{n}$ korkuista, 1250 - 2000 1/ha, kun käytetään selässä kannettavia paineruiskuja. Tekohormoniruiskutus on suoritettava niin, että vesojen kaikki oksat joutuvat liuoksen kanssa kosketukseen. Yhdellä kertaa on käsittelyä käytännössä vaikea saada kyllin tarkkaan tehdyksi. Sen vuoksi on tärkeätä suorittaa $2-3$ viikon kuluttua tarkistusruiskutus. Käsittely tehoaa parhaiten lämpimillä ilmoilla suoritettuna. Parhaaseen tulokseen päästään, kun vesakot ruiskutetaan kesäkuun jälkipuoliskolla tai heinäkuun alussa. Varhain keväällä käsiteltäessä kehittyy runkoihin ja oksiin runsaasti uusia vesoja; myöhään kesällä käsiteltäessä taasen tekohormoni ei tapa tehokkaasti lehtiä. Nuorien puukasvien lehdet kuolevat herkemmin kuin vanhojen. Lepän vesojen jälleenkasvu voidaan estää yhtenä kesänä suoritetulla tekohormoniruiskutuksella melkein täydellisesti, mikäli ne eivät ole lähtöisin kovin suurikokoisten puiden kannoista. Pajulla, koivulla, pihlajalla ja haavalla ilmenee seuraavana kesänä usein lievää jälleenkasvua. Tekohormoniruiskutuksilla saadut tulokset käyvät yksiin — vähäisiä poikkeuksia lukuunottamatta - aikaisempien tutkimuksien kanssa $(1,4,5,6,12,23,24)$.

Kloraatti- ja kresoliruiskutuksilla on mahdollista tappaa puukasvien lehdet, mutta uusien vesojen muodostumista tällainen käsittely ei estä.

Kokeiltujen tekohormonityyppien vesiliuokset voidaan tehokkaasti imeyttää leppiin katkaistusta oksasta (kuva 9). Veteenliukenemattomilla tekohormoneilla tämä ei onnistu. Laimeat liuokset imeytyvät helpommin kuin väkevät. Tehoavan aineen kulutus muodostuu kuitenkin viimeksimainituissa suuremmaksi kuin edellisissä. Verraten suurikokoiset lepät voidaan täten hävittää juurineen. 
Sen sijaan suurikokoiset pajut, koivut, pihlajat ja haavat eivät tuhoudu, jos imeyttäminen suoritetaan ainoastaan yhdestä oksasta. Liuoksen kulutus muodostuu lepälläkin niin suureksi, ettei menetelmää voida suositella käytäntöön. Katkaistusta oksasta imeytetyt liuokset kulkeutuvat kasvin eri osiin pääasiallisesti puuosassa. Haihtumisvirtauksen vuoksi niiden siirtyminen puussa alaspäin on hyvin hankalaa. Jos kuitenkin haihtumisvirtaus poistetaan katkaisemalla runko johto-oksan yläpuolelta, tapahtuu liuoksen kulkeutuminen juuriin päin tehokkaasti, ainakin heinä- ja elokuussa. Tämän perusteella on esitetty, että korkeakasvuiset vesakot, samoin kuin suurikokoiset puut ja pensaat, joiden kannoista vesat tavallisesti kehittyvät, olisi edullisinta hävittää imeyttämällä tekohormonia katkaistun puukasvin kantoon. Menetelmän käyttökelpoisuus kaipaa kokeellista selvittämistä.

Myös kloraatti- ja kresoliliuokset imeytyvät katkaistusta oksasta leppiin. Niiden imeytymisen tehokkuus on kuitenkin selvittämättä.

Käsittelemällä maata edellä mainituilla tekohormonityypeillä, koloraatilla tai kresolilla ei vesakkoja voida kannattavasti hävittää. 